Finanse, Rynki Finansowe, Ubezpieczenia nr 2/2017 (86)

DOI: $10.18276 /$ frfu.2017.86-29

s. $353-362$

\title{
Emerging market regularities - the case of monthly effects on the Warsaw Stock Exchange
}

\author{
Joanna Lizińska*
}

\begin{abstract}
Purpose - Seasonality of equity returns has been widely discussed, mainly in relation to the efficient market theory. The study focuses on the re-examination of monthly anomalies for the Polish emerging market, incorporating the fact that the market has grown and developed in recent last years.

Design/Methodology/approach - The empirical study is focused on equity market returns, considering the regularity of various seasonal anomalies on the Warsaw Stock Exchange during 1995-2015. Monthly equity returns, half-of-the-month effect, January barometer and turn-of-the-month effect are analysed with a buy-and-hold and cumulative approach.

Findings - Differences in average monthly returns seem to be pronounced. The differences between the first and the second half of the month become considerable for small companies where averagely higher returns were reported for the second half of the month. The average returns for the turn-of-the-month periods were reported in comparison to the rest of the month. The January barometer anomaly was observed most often for small companies.

Originality/Value - The paper discusses monthly Polish security market regularities for all companies during 1995-2015. Moreover, the size effects for companies are checked for monthly anomalies.
\end{abstract}

Keywords: emerging market, market anomalies, calendar effects, seasonal anomalies, monthly anomalies

\section{Introduction}

An explosion of anomaly research has been observed in recent years. The research into market anomalies concentrates on several issues such as market rationality, the efficient market hypothesis, complete knowledge of the economic structure, investor irrationality, incomplete information, stock returns determinants or the behavioural background of investors' decisions. Anomalies either challenge the concept of the efficient market hypothesis tempting market participants and researchers with extra profits for some equity portfolios or they inspire heated discussion about the validity of pricing models (e.g Agrawal, Tandon, 1994; Dzhabarov, Ziemba, 2010).

Anomalies can be defined as empirical findings inconsistent with the predictions of accepted asset pricing models. They can be perceived either in a context of market inefficiency or inadequacies in the underlying asset pricing models. Detection of market anomalies encompasses essentially two steps: identification of a mispricing signal and evaluating its importance. Many

\footnotetext{
* dr Joanna Lizińska, Uniwersytet Ekonomiczny w Poznaniu, Katedra Finansów Przedsiębiorstw, e-mail: joanna. lizinska@ue.poznan.pl
} 
such signals have been revealed so far, mainly for US markets. The most prominent market anomalies include those connected with seasonal effects, company fundamentals or other broadly defined stock characteristics, or important company events and decisions. Seasonal anomalies have the longest history in academic literature. Anomalies of the seasonal variety have been linked with the Holiday effect (Lakonishok, Smidt, 1988), the Weekend effect (French, 1980), the January Effect (Thaler, 1987), Turn-of-the-Month Effect (Ariel, 1987), Dayof-the-Week Effects (Gibbons, Hess, 1981), or the January Barometer (Hensel, Ziemba, 1995).

Market anomalies have been studied for the Warsaw Stock Exchange especially for the first stage of the market's development (e.g. Tarczyński, 1997; Szyszka, 1999; Czekaj, Woś, Żarnowski, 2001; Szyszka, 2003; Szkrodzka, Włodarczyk, 2004; Zarzecki, Malec, 2007). The recent studies involve papers such as Dudzińska-Baryła and Michalska (2010), Fiszeder and Kożuchowska (2013) or Waszkowski (2013).

Some cases of seasonal price behaviour prove that anomalies do not disappear with time, even after the moment they were detected for some markets. But some seasonal effects weaken or reverse themselves. Hence, the need to develop empirical studies on market anomalies, especially for emerging markets is well-founded. This study was financed by the National Science Centre, Poland as a research project (2015/19/D/HS4/01950) and it is an introductory study to the broad and multidimensional analysis of seasonal anomalies.

The research period covers 1995 to 2015 and focuses both on market returns for all companies as well as for small and large companies listed on the Warsaw Stock Exchange in Poland (WSE). The level of main Polish indexes during the period has fluctuated. In consequence, monthly anomalies will be analysed over bear and bull market conditions, also covering periods of very rapid change.

The rest of the paper is structured in the following way. In the following section differences in monthly returns are analysed. Section 2 describes Half-of-the-Month Effects. In section 3 the Turn-of-the-Month Effect is discussed. In section 4, January as a signal for the returns in following months is checked. The last section states the conclusions.

\section{Monthly returns}

Daily index returns were calculated for the period 1995-2015 for the main Polish indexes. Then, average statistics were calculated for each month of the sample period. Average cumulative daily returns, buy-and-hold returns, mean daily returns and standard deviation of daily returns for each month were observed.

The research focused on seasonal differences in returns for all companies listed on the WSE, which was approximated by the main Polish equity index WIG. The results are presented in table 1 . To capture the size differences in returns for companies, returns for small and large companies were also observed, and the analysis was based on sWIG80 and WIG20, respectively. The results are detailed in table 2 . 


\section{Table 1}

Average WIG returns by month

\begin{tabular}{|c|c|c|c|c|}
\hline Month & Cum & BHR & Mean & Std \\
\hline 1.Jan & $2.77 \%$ & $1.57 \%$ & $0.13 \%$ & $1.53 \%$ \\
\hline 2.Feb & $1.43 \%$ & $0.69 \%$ & $0.07 \%$ & $1.40 \%$ \\
\hline 3.Mar & $1.09 \%$ & $1.19 \%$ & $0.05 \%$ & $1.29 \%$ \\
\hline 4.Apr & $4.24 \%$ & $4.28 \%$ & $0.22 \%$ & $1.28 \%$ \\
\hline 5.May & $-0.84 \%$ & $-1.32 \%$ & $-0.04 \%$ & $1.30 \%$ \\
\hline 6.Jun & $0.30 \%$ & $0.48 \%$ & $0.02 \%$ & $1.19 \%$ \\
\hline 7.Jul & $1.33 \%$ & $1.38 \%$ & $0.06 \%$ & $1.16 \%$ \\
\hline 8.Aug & $-0.10 \%$ & $0.25 \%$ & $0.00 \%$ & $1.36 \%$ \\
\hline 9.Sep & $-0.60 \%$ & $-0.49 \%$ & $-0.03 \%$ & $1.36 \%$ \\
\hline $10.0 c t$ & $-0.12 \%$ & $0.27 \%$ & $0.00 \%$ & $1.45 \%$ \\
\hline 11.Nov & $-0.18 \%$ & $-1.07 \%$ & $-0.01 \%$ & $1.31 \%$ \\
\hline 12.Dec & $2.08 \%$ & $1.77 \%$ & $0.10 \%$ & $1.11 \%$ \\
\hline
\end{tabular}

Source: own calculation.

Table 2

Average index returns by month - size effect

\begin{tabular}{|c|c|c|c|c|}
\hline Month & Cum & BHR & Mean & Std \\
\hline \multicolumn{5}{|c|}{ Panel A: s WIG80 } \\
\hline 1.Jan & $2.93 \%$ & $2.21 \%$ & $0.14 \%$ & $1.39 \%$ \\
\hline 2.Feb & $4.21 \%$ & $3.32 \%$ & $0.21 \%$ & $1.42 \%$ \\
\hline 3.Mar & $2.50 \%$ & $3.04 \%$ & $0.11 \%$ & $1.16 \%$ \\
\hline 4.Apr & $4.41 \%$ & $4.53 \%$ & $0.23 \%$ & $1.17 \%$ \\
\hline 5.May & $-0.27 \%$ & $-1.09 \%$ & $-0.02 \%$ & $1.31 \%$ \\
\hline 6.Jun & $-0.89 \%$ & $-0.75 \%$ & $-0.04 \%$ & $1.10 \%$ \\
\hline 7.Jul & $-0.49 \%$ & $-0.10 \%$ & $-0.02 \%$ & $1.00 \%$ \\
\hline 8.Aug & $0.34 \%$ & $1.07 \%$ & $0.02 \%$ & $1.23 \%$ \\
\hline 9.Sep & $-0.33 \%$ & $-0.09 \%$ & $-0.01 \%$ & $1.20 \%$ \\
\hline $10.0 c t$ & $0.35 \%$ & $0.66 \%$ & $0.02 \%$ & $1.14 \%$ \\
\hline 11.Nov & $-0.04 \%$ & $-0.83 \%$ & $0.00 \%$ & $1.14 \%$ \\
\hline 12.Dec & $2.14 \%$ & $1.91 \%$ & $0.10 \%$ & $1.06 \%$ \\
\hline \multicolumn{5}{|c|}{ Panel B: WIG20 } \\
\hline 1.Jan & $2.29 \%$ & $1.02 \%$ & $0.11 \%$ & $1.76 \%$ \\
\hline 2.Feb & $1.27 \%$ & $0.42 \%$ & $0.06 \%$ & $1.63 \%$ \\
\hline 3.Mar & $0.81 \%$ & $0.79 \%$ & $0.03 \%$ & $1.55 \%$ \\
\hline 4.Apr & $3.77 \%$ & $4.09 \%$ & $0.20 \%$ & $1.52 \%$ \\
\hline 5.May & $-1.52 \%$ & $-1.91 \%$ & $-0.08 \%$ & $1.53 \%$ \\
\hline 6.Jun & $-0.22 \%$ & $-0.13 \%$ & $-0.01 \%$ & $1.46 \%$ \\
\hline 7.Jul & $0.76 \%$ & $0.77 \%$ & $0.03 \%$ & $1.38 \%$ \\
\hline 8.Aug & $-0.29 \%$ & $0.03 \%$ & $-0.01 \%$ & $1.61 \%$ \\
\hline $9 . S e p$ & $-1.40 \%$ & $-1.55 \%$ & $-0.07 \%$ & $1.63 \%$ \\
\hline 10.Oct & $0.59 \%$ & $0.87 \%$ & $0.03 \%$ & $1.85 \%$ \\
\hline 11.Nov & $-0.05 \%$ & $-1.33 \%$ & $-0.01 \%$ & $1.59 \%$ \\
\hline 12.Dec & $2.22 \%$ & $1.95 \%$ & $0.11 \%$ & $1.36 \%$ \\
\hline
\end{tabular}

Source: own calculation. 
The differences between months of the year are pronounced. April, January, December and February were the bull months on the Polish stock exchange. The bear months were May, September, November and October. The average monthly cumulative (buy-and-hold) returns for the market for the best month (April) equalled 4.24\% (4.28\%), whereas for the worst month (May) it was negative $-0.84 \%(-1.32 \%)$.

Monthly returns for small companies seemed to be higher in the first four months of the year, which were the bull month for the WSE. However, the average returns for June and July were negative for small companies, although these months were averagely positive for both large companies and the whole market.

The volatility of average monthly returns seems to grow weaker in the sample period. However, no pronounced tendencies in average monthly returns for the positive and negative months were seen during the 21-year period.

\section{Half-of-the-month effect}

The analysis of the differences between average returns for months was broadened into half-of-the-month effects. Daily returns were classified into the first and the second half of each month and then aggregated across both subsamples. The results for all companies are detailed in table 3. Table 4 shows average returns for small and large companies.

Table 3

Half-of-the-Month Effect - for all companies

\begin{tabular}{|c|c|c|c|c|c|c|c|c|c|}
\hline \multirow{2}{*}{ Mth } & Cum & Cum & BHR & Mean & Std & Cum & BHR & Mean & Std \\
\hline & Whole month & \multicolumn{4}{|c|}{ 1st half of month } & \multicolumn{4}{|c|}{ 2nd half of month } \\
\hline 1.Jan & $2.77 \%$ & $1.63 \%$ & $0.23 \%$ & $0.14 \%$ & $1.60 \%$ & $1.14 \%$ & $0.55 \%$ & $0.11 \%$ & $1.35 \%$ \\
\hline 2.Feb & $1.43 \%$ & $1.93 \%$ & $1.17 \%$ & $0.19 \%$ & $1.43 \%$ & $-0.50 \%$ & $-0.72 \%$ & $-0.05 \%$ & $1.37 \%$ \\
\hline 3.Mar & $1.09 \%$ & $0.43 \%$ & $0.56 \%$ & $0.03 \%$ & $1.34 \%$ & $0.65 \%$ & $0.58 \%$ & $0.06 \%$ & $1.18 \%$ \\
\hline 4.Apr & $4.24 \%$ & $2.69 \%$ & $2.52 \%$ & $0.27 \%$ & $1.17 \%$ & $1.55 \%$ & $1.31 \%$ & $0.17 \%$ & $1.40 \%$ \\
\hline 5.May & $-0.84 \%$ & $-0.88 \%$ & $-1.32 \%$ & $-0.08 \%$ & $1.19 \%$ & $0.04 \%$ & $-0.30 \%$ & $0.00 \%$ & $1.35 \%$ \\
\hline 6.Jun & $0.30 \%$ & $0.01 \%$ & $0.11 \%$ & $0.01 \%$ & $1.22 \%$ & $0.29 \%$ & $0.35 \%$ & $0.03 \%$ & $1.11 \%$ \\
\hline 7.Jul & $1.33 \%$ & $0.77 \%$ & $0.77 \%$ & $0.07 \%$ & $1.14 \%$ & $0.57 \%$ & $0.26 \%$ & $0.05 \%$ & $1.14 \%$ \\
\hline 8.Aug & $-0.10 \%$ & $-1.41 \%$ & $-1.13 \%$ & $-0.12 \%$ & $1.31 \%$ & $1.31 \%$ & $1.24 \%$ & $0.12 \%$ & $1.33 \%$ \\
\hline 9.Sep & $-0.60 \%$ & $0.55 \%$ & $0.66 \%$ & $0.05 \%$ & $1.42 \%$ & $-1.15 \%$ & $-1.19 \%$ & $-0.11 \%$ & $1.27 \%$ \\
\hline $10.0 \mathrm{ct}$ & $-0.12 \%$ & $0.05 \%$ & $0.42 \%$ & $0.00 \%$ & $1.36 \%$ & $-0.17 \%$ & $0.14 \%$ & $-0.01 \%$ & $1.42 \%$ \\
\hline 11.Nov & $-0.18 \%$ & $0.17 \%$ & $-0.67 \%$ & $0.01 \%$ & $1.33 \%$ & $-0.35 \%$ & $-0.40 \%$ & $-0.03 \%$ & $1.23 \%$ \\
\hline 12.Dec & $2.08 \%$ & $0.90 \%$ & $0.59 \%$ & $0.08 \%$ & $1.11 \%$ & $1.18 \%$ & $1.31 \%$ & $0.11 \%$ & $1.06 \%$ \\
\hline $1-12$ & $0.95 \%$ & $0.57 \%$ & $0.33 \%$ & $0.05 \%$ & $1.30 \%$ & $0.38 \%$ & $0.26 \%$ & $0.04 \%$ & $1.27 \%$ \\
\hline
\end{tabular}

Source: own calculation. 


\section{Table 4}

Half-of-the-Month Effect - size effect

\begin{tabular}{|c|c|c|c|c|c|c|c|c|c|}
\hline \multirow{2}{*}{ Mth } & Cum & Cum & BHR & Mean & Std & Cum & BHR & Mean & Std \\
\hline & Whole month & \multicolumn{4}{|c|}{ 1st half of month } & \multicolumn{4}{|c|}{ 2nd half of month } \\
\hline \multicolumn{10}{|c|}{ Panel A: s WIG80 } \\
\hline 1.Jan & $2.93 \%$ & $1.06 \%$ & $0.27 \%$ & $0.09 \%$ & $1.36 \%$ & $1.86 \%$ & $1.10 \%$ & $0.18 \%$ & $1.25 \%$ \\
\hline 2.Feb & $4.21 \%$ & $3.28 \%$ & $2.38 \%$ & $0.32 \%$ & $1.45 \%$ & $0.93 \%$ & $0.67 \%$ & $0.09 \%$ & $1.35 \%$ \\
\hline 3.Mar & $2.50 \%$ & $0.56 \%$ & $0.97 \%$ & $0.04 \%$ & $1.22 \%$ & $1.94 \%$ & $1.56 \%$ & $0.19 \%$ & $1.01 \%$ \\
\hline 4.Apr & $4.41 \%$ & $2.15 \%$ & $1.98 \%$ & $0.22 \%$ & $1.01 \%$ & $2.26 \%$ & $1.78 \%$ & $0.24 \%$ & $1.33 \%$ \\
\hline 5.May & $-0.27 \%$ & $-0.09 \%$ & $-0.93 \%$ & $-0.01 \%$ & $1.22 \%$ & $-0.17 \%$ & $-0.18 \%$ & $-0.02 \%$ & $1.30 \%$ \\
\hline 6.Jun & $-0.89 \%$ & $-1.63 \%$ & $-1.44 \%$ & $-0.15 \%$ & $1.11 \%$ & $0.73 \%$ & $0.55 \%$ & $0.07 \%$ & $0.99 \%$ \\
\hline 7.Jul & $-0.49 \%$ & $-0.71 \%$ & $-0.47 \%$ & $-0.06 \%$ & $0.87 \%$ & $0.23 \%$ & $-0.14 \%$ & $0.02 \%$ & $1.02 \%$ \\
\hline 8.Aug & $0.34 \%$ & $-1.21 \%$ & $-0.70 \%$ & $-0.10 \%$ & $1.15 \%$ & $1.56 \%$ & $1.27 \%$ & $0.15 \%$ & $1.20 \%$ \\
\hline 9.Sep & $-0.33 \%$ & $0.21 \%$ & $0.48 \%$ & $0.02 \%$ & $1.23 \%$ & $-0.54 \%$ & $-0.38 \%$ & $-0.05 \%$ & $1.10 \%$ \\
\hline $10.0 c t$ & $0.35 \%$ & $0.07 \%$ & $0.32 \%$ & $0.00 \%$ & $1.05 \%$ & $0.27 \%$ & $0.08 \%$ & $0.03 \%$ & $1.18 \%$ \\
\hline 11.Nov & $-0.04 \%$ & $-0.46 \%$ & $-1.21 \%$ & $-0.04 \%$ & $1.09 \%$ & $0.43 \%$ & $0.31 \%$ & $0.04 \%$ & $1.11 \%$ \\
\hline 12.Dec & $2.14 \%$ & $0.14 \%$ & $-0.06 \%$ & $0.01 \%$ & $0.90 \%$ & $2.00 \%$ & $2.23 \%$ & $0.20 \%$ & $1.13 \%$ \\
\hline $1-12$ & $1.24 \%$ & $0.28 \%$ & $0.13 \%$ & $0.03 \%$ & $1.14 \%$ & $0.96 \%$ & $0.74 \%$ & $0.09 \%$ & $1.16 \%$ \\
\hline \multicolumn{10}{|c|}{ Panel B: WIG80 } \\
\hline 1.Jan & $2.29 \%$ & $1.73 \%$ & $0.23 \%$ & $0.15 \%$ & $1.89 \%$ & $0.57 \%$ & $0.26 \%$ & $0.05 \%$ & $1.54 \%$ \\
\hline 2.Feb & $1.27 \%$ & $1.60 \%$ & $0.70 \%$ & $0.15 \%$ & $1.66 \%$ & $-0.33 \%$ & $-0.64 \%$ & $-0.03 \%$ & $1.62 \%$ \\
\hline 3.Mar & $0.81 \%$ & $0.29 \%$ & $0.29 \%$ & $0.02 \%$ & $1.65 \%$ & $0.52 \%$ & $0.51 \%$ & $0.05 \%$ & $1.39 \%$ \\
\hline 4.Apr & $3.77 \%$ & $2.78 \%$ & $2.95 \%$ & $0.28 \%$ & $1.45 \%$ & $0.99 \%$ & $0.84 \%$ & $0.11 \%$ & $1.59 \%$ \\
\hline 5.May & $-1.52 \%$ & $-1.27 \%$ & $-1.57 \%$ & $-0.12 \%$ & $1.42 \%$ & $-0.26 \%$ & $-0.48 \%$ & $-0.03 \%$ & $1.57 \%$ \\
\hline 6.Jun & $-0.22 \%$ & $0.11 \%$ & $0.11 \%$ & $0.02 \%$ & $1.49 \%$ & $-0.33 \%$ & $0.01 \%$ & $-0.03 \%$ & $1.34 \%$ \\
\hline 7.Jul & $0.76 \%$ & $0.53 \%$ & $0.52 \%$ & $0.05 \%$ & $1.31 \%$ & $0.24 \%$ & $0.12 \%$ & $0.02 \%$ & $1.39 \%$ \\
\hline 8.Aug & $-0.29 \%$ & $-1.41 \%$ & $-1.17 \%$ & $-0.12 \%$ & $1.66 \%$ & $1.12 \%$ & $1.21 \%$ & $0.11 \%$ & $1.51 \%$ \\
\hline 9.Sep & $-1.40 \%$ & $0.21 \%$ & $0.07 \%$ & $0.02 \%$ & $1.69 \%$ & $-1.61 \%$ & $-1.76 \%$ & $-0.16 \%$ & $1.54 \%$ \\
\hline 10.Oct & $0.59 \%$ & $0.23 \%$ & $0.60 \%$ & $0.01 \%$ & $1.68 \%$ & $0.36 \%$ & $0.38 \%$ & $0.04 \%$ & $1.87 \%$ \\
\hline 11.Nov & $-0.05 \%$ & $0.33 \%$ & $-0.90 \%$ & $0.03 \%$ & $1.67 \%$ & $-0.38 \%$ & $-0.32 \%$ & $-0.03 \%$ & $1.44 \%$ \\
\hline 12.Dec & $2.22 \%$ & $0.86 \%$ & $0.61 \%$ & $0.08 \%$ & $1.39 \%$ & $1.35 \%$ & $1.57 \%$ & $0.13 \%$ & $1.30 \%$ \\
\hline $1-12$ & $0.69 \%$ & $0.50 \%$ & $0.20 \%$ & $0.05 \%$ & $1.58 \%$ & $0.19 \%$ & $0.14 \%$ & $0.02 \%$ & $1.51 \%$ \\
\hline
\end{tabular}

Source: own calculation.

On average, slightly higher market returns were reported in the first half of the month. The difference equalled 0.19 percentage points (pp.) as measured with the mean monthly cumulative returns and the difference between mean monthly buy-and-hold was much smaller (0.06 pp.). Similar results were observed for large companies as the average monthly cumulative and buyand-hold returns were higher for the first half of the month and differ by $0.31 \mathrm{pp}$. and $0.06 \mathrm{pp}$., respectively. The disparity between average returns for both parts of the month becomes considerable for small companies. On the contrary, averagely higher returns were reported for the second half of the month. Such a relation for average returns was observed in ten out of twelve months. Mean monthly cumulative and buy-and-hold returns differed by $0.68 \mathrm{pp}$. and $0.60 \mathrm{pp}$., respectively.

However, the differences are not so prominent if we look at the relative number of positive cumulative returns for the 252 months in the sample period. The market reported $56 \%$ and $52 \%$ of months where returns were positive in the first and second halves of the month, respectively. For large companies it was $54 \%$ and $49 \%$, respectively. Conversely, monthly cumulative returns for small companies were positive in $60 \%$ of first halves in comparison to $54 \%$ of the second parts of the month. 
However, the differences in average cumulative returns between the second and the first half of each of the 252 months of the sample period changed during 1995-2015. For the first decade (1995-2004) mean monthly cumulative returns for the first half of the month were higher by 1.1 pp., 0.22 pp. and 1.15 pp. for the WIG, sWIG80 and WIG20, respectively. For the most recent years, mainly during the period 2005-2015, the analogous returns were higher in the second half of the month and equalled 0.74 pp., $1.52 \mathrm{pp}$. and 0.56 pp., respectively.

\section{Turn-of-the-month effect}

Ariel (1987) first documented for the United States that there have been high returns around the turn-of-the-month (TOM). This effect was later analysed for different periods and markets (e.g. Dzhabarov, Ziemba, 2011; Booth, Kallunki, Martikainen, 2001; Cadsby, Ratner, 1992; or Khaled, Keef, 2012).

\section{Table 5}

Average Returns for the Turn-of-the-Month Effect

\begin{tabular}{|c|c|c|c|c|c|c|}
\hline & \multicolumn{3}{|c|}{ Cum } & \multicolumn{3}{|c|}{ Mean } \\
\hline & before $<-6 ;-2>$ & TOM $<-1 ;+4>$ & after $<+5 ;+9>$ & before $<-6 ;-2>$ & TOM $<-1 ;+4>$ & after $<+5 ;+9>$ \\
\hline \multicolumn{7}{|c|}{ Panel A: All months } \\
\hline WIG & $0.10 \%$ & $0.74 \%$ & $-0.02 \%$ & $0.02 \%$ & $0.15 \%$ & $0.00 \%$ \\
\hline s WIG80 & $0.49 \%$ & $0.60 \%$ & $0.09 \%$ & $0.10 \%$ & $0.12 \%$ & $0.02 \%$ \\
\hline WIG20 & $-0.01 \%$ & $0.81 \%$ & $-0.08 \%$ & $0.00 \%$ & $0.16 \%$ & $-0.02 \%$ \\
\hline \multicolumn{7}{|c|}{ Panel B: Most positve months } \\
\hline$\overline{\mathrm{WIG}}$ & $0.59 \%$ & $1.42 \%$ & $0.40 \%$ & $0.12 \%$ & $0.28 \%$ & $0.08 \%$ \\
\hline sWIG80 & $1.10 \%$ & $1.36 \%$ & $0.63 \%$ & $0.22 \%$ & $0.27 \%$ & $0.13 \%$ \\
\hline WIG20 & $0.51 \%$ & $1.73 \%$ & $0.17 \%$ & $0.10 \%$ & $0.35 \%$ & $0.03 \%$ \\
\hline \multicolumn{7}{|c|}{ Panel C: Most negative months } \\
\hline$\overline{\mathrm{WIG}}$ & $-0.24 \%$ & $0.44 \%$ & $-0.22 \%$ & $-0.05 \%$ & $0.09 \%$ & $-0.04 \%$ \\
\hline s WIG80 & $0.25 \%$ & $0.24 \%$ & $0.04 \%$ & $0.05 \%$ & $0.05 \%$ & $0.01 \%$ \\
\hline WIG20 & $-0.31 \%$ & $0.38 \%$ & $-0.09 \%$ & $-0.06 \%$ & $0.08 \%$ & $-0.02 \%$ \\
\hline
\end{tabular}

Source: own calculation.

Daily returns were classified into five-day event windows around the turn of each month: before TOM, TOM and after TOM, where was the last day of the previous month and was the first day of the month. The results for all months and additionally for most positive and negative months (derived from section 1) are shown in table 5 with average cumulative returns additionally presented on figure 1.

The average returns for the five days covering the turn-of-the-month were higher in comparison to the five-day periods before and after the TOM. It was observed as well for the whole market as for the large and small companies. Average positive returns were even recorded during the TOM days for bear months. 


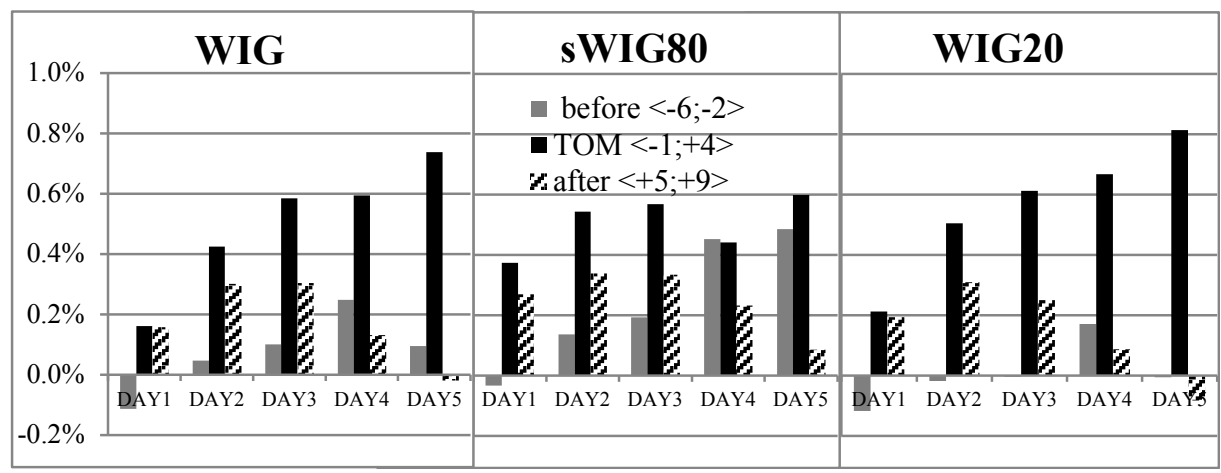

Figure 1. Cumulative Index Returns around Turn-of-the-Month

Source: own calculation.

\section{January barometer}

Hensel and Ziemba (1995) and Hirsch (1986, citation according to Brown, Luo, 2006) first documented the January barometer effect. Returns in January are treated as a signal for returns in the rest of the year. If the returns are positive in January, then the rest of the year is also expected to be positive. If they are negative in January, then a bear year is expected.

Mean daily returns were calculated for each January. Then, each January was classified as positive (JAN+) or negative (JAN-). In the next step, mean daily index returns for the rest of the year (ROY) were calculated for both groups in each year. At the beginning, the rest of the year was defined as months from February to December. The results for all, small and large companies are presented in table 6 and the average results for 1995-2015 are presented in Panel A of table 7.

As the results in section 1 demonstrate very high returns in the last month of the year, December was excluded from the ROY, which is averaged for 1995-2015 in Panels B and $\mathrm{C}$ of table 7. The beginning of each month is also expected to have very specific returns in comparison to other days of a month as presented in the TOM section. Hence, the accordance of the returns' sign in January and the rest of the year was also checked for the case where only the first five days of January are a signal for the returns during the ROY. The results are presented in Panel C of table 7.

January worked as barometer for the rest of the year most often for small companies, no matter whether returns from the whole of January or just five days approximated the rest of the year. However, the anomaly was not so pronounced for all companies where its existence remains disputable. For large companies it is also hard to find arguments in favour of this anomaly. 
Table 6

Average Index Returns for the January Barometer Effect by Years

\begin{tabular}{|c|c|c|c|c|c|c|c|c|c|}
\hline \multirow{3}{*}{ Year } & \multicolumn{3}{|c|}{ WIG } & \multicolumn{3}{|c|}{ sWIG80 } & \multicolumn{3}{|c|}{ WIG20 } \\
\hline & \multirow{2}{*}{ JAN } & \multicolumn{2}{|c|}{ ROY } & \multirow{2}{*}{ JAN } & \multicolumn{2}{|c|}{ ROY } & \multirow{2}{*}{ JAN } & \multicolumn{2}{|c|}{ ROY } \\
\hline & & $\mathrm{JAN}(+)$ & JAN(-) & & $\mathrm{JAN}(+)$ & JAN(-) & & $\mathrm{JAN}(+)$ & JAN(-) \\
\hline 1995 & $-0.86 \%$ & & $0.12 \%$ & $-0.68 \%$ & & $0.12 \%$ & $-0.83 \%$ & & $0.14 \%$ \\
\hline 1996 & $1.46 \%$ & $0.15 \%$ & & $0.80 \%$ & $0.37 \%$ & & $1.51 \%$ & $0.13 \%$ & \\
\hline 1997 & $0.58 \%$ & $-0.03 \%$ & & $0.19 \%$ & $0.10 \%$ & & $0.61 \%$ & $-0.01 \%$ & \\
\hline 1998 & $-0.08 \%$ & & $-0.02 \%$ & $-0.17 \%$ & & $-0.25 \%$ & $0.05 \%$ & $-0.03 \%$ & \\
\hline 1999 & $0.71 \%$ & $0.10 \%$ & & $-0.46 \%$ & & $0.14 \%$ & $0.49 \%$ & $0.13 \%$ & \\
\hline 2000 & $0.37 \%$ & $-0.02 \%$ & & $0.33 \%$ & $0.11 \%$ & & $0.34 \%$ & $0.00 \%$ & \\
\hline 2001 & $-0.06 \%$ & & $-0.09 \%$ & $-0.28 \%$ & & $-0.16 \%$ & $-0.10 \%$ & & $-0.15 \%$ \\
\hline 2002 & $0.67 \%$ & $-0.04 \%$ & & $-0.17 \%$ & & $-0.09 \%$ & $0.84 \%$ & $-0.08 \%$ & \\
\hline 2003 & $-0.19 \%$ & & $0.19 \%$ & $0.26 \%$ & $0.29 \%$ & & $-0.26 \%$ & & $0.16 \%$ \\
\hline 2004 & $0.23 \%$ & $0.09 \%$ & & $0.63 \%$ & $0.19 \%$ & & $0.13 \%$ & $0.09 \%$ & \\
\hline 2005 & $-0.11 \%$ & & $0.14 \%$ & $0.03 \%$ & $0.06 \%$ & & $-0.18 \%$ & & $0.15 \%$ \\
\hline 2006 & $0.29 \%$ & $0.13 \%$ & & $1.03 \%$ & $0.28 \%$ & & $0.26 \%$ & $0.08 \%$ & \\
\hline 2007 & $0.37 \%$ & $0.02 \%$ & & $0.59 \%$ & $0.05 \%$ & & $0.28 \%$ & $0.01 \%$ & \\
\hline 2008 & $-0.67 \%$ & & $-0.23 \%$ & $-0.49 \%$ & & $-0.31 \%$ & $-0.69 \%$ & & $-0.19 \%$ \\
\hline 2009 & $-0.46 \%$ & & $0.22 \%$ & $-0.18 \%$ & & $0.23 \%$ & $-0.52 \%$ & & $0.19 \%$ \\
\hline 2010 & $0.01 \%$ & $0.08 \%$ & & $0.19 \%$ & $0.03 \%$ & & $-0.01 \%$ & & $0.07 \%$ \\
\hline 2011 & $-0.03 \%$ & & $-0.09 \%$ & $0.12 \%$ & $-0.16 \%$ & & $-0.07 \%$ & & $-0.09 \%$ \\
\hline 2012 & $0.41 \%$ & $0.07 \%$ & & $0.49 \%$ & $0.05 \%$ & & $0.41 \%$ & $0.05 \%$ & \\
\hline 2013 & $-0.06 \%$ & & $0.05 \%$ & $0.34 \%$ & $0.11 \%$ & & $-0.16 \%$ & & $-0.01 \%$ \\
\hline 2014 & $-0.08 \%$ & & $0.01 \%$ & $-0.02 \%$ & & $-0.07 \%$ & $-0.13 \%$ & & $0.00 \%$ \\
\hline 2015 & $0.07 \%$ & $-0.04 \%$ & & $0.15 \%$ & $0.03 \%$ & & $0.07 \%$ & $-0.09 \%$ & \\
\hline
\end{tabular}

Source: own calculation.

Table 7

Mean Index Returns for the January Barometer Effect by Years - robustness check

\begin{tabular}{|c|c|c|c|c|c|c|c|c|c|}
\hline \multirow{3}{*}{ Year } & \multicolumn{3}{|c|}{ WIG } & \multicolumn{3}{|c|}{ sWIG80 } & \multicolumn{3}{|c|}{ WIG20 } \\
\hline & \multirow{2}{*}{ JAN } & \multicolumn{2}{|c|}{ ROY } & \multirow{2}{*}{ JAN } & \multicolumn{2}{|c|}{ ROY } & \multirow{2}{*}{ JAN } & \multicolumn{2}{|c|}{ ROY } \\
\hline & & $\mathrm{JAN}(+)$ & JAN(-) & & $\mathrm{JAN}(+)$ & JAN(-) & & $\mathrm{JAN}(+)$ & $\mathrm{JAN}(-)$ \\
\hline \multicolumn{10}{|c|}{ Panel A: JAN=whole month; ROY=<Feb;Dec $>$} \\
\hline Śr. & $0.12 \%$ & $0.05 \%$ & $0.03 \%$ & $0.13 \%$ & $0.12 \%$ & $-0.05 \%$ & $0.10 \%$ & $0.02 \%$ & $0.03 \%$ \\
\hline $\mathbf{N}$ & 21 & 11 & 10 & 21 & 13 & 8 & 21 & 11 & 10 \\
\hline$\%>0$ & $52 \%$ & $64 \%$ & $60 \%$ & $62 \%$ & $92 \%$ & $38 \%$ & $52 \%$ & $55 \%$ & $60 \%$ \\
\hline \multicolumn{10}{|c|}{ Panel B: JAN=whole month; ROY=<Feb;Nov $>$} \\
\hline Śr. & $0.12 \%$ & $0.03 \%$ & $0.03 \%$ & $0.13 \%$ & $0.12 \%$ & $-0.07 \%$ & $0.10 \%$ & $0.01 \%$ & $0.03 \%$ \\
\hline $\mathbf{N}$ & 21 & 11 & 10 & 21 & 13 & 8 & 21 & 11 & 10 \\
\hline$\%>0$ & $52 \%$ & $64 \%$ & $60 \%$ & $62 \%$ & $92 \%$ & $38 \%$ & $52 \%$ & $55 \%$ & $70 \%$ \\
\hline \multicolumn{10}{|c|}{ Panel C: JAN=5 trading days; ROY $=<$ Feb;Nov $>$} \\
\hline Śr. & $0.12 \%$ & $0.07 \%$ & $-0.02 \%$ & $0.13 \%$ & $0.16 \%$ & $-0.11 \%$ & $0.10 \%$ & $0.06 \%$ & $-0.03 \%$ \\
\hline $\mathbf{N}$ & 21 & 12 & 9 & 21 & 12 & 9 & 21 & 12 & 9 \\
\hline$\%>0$ & $52 \%$ & $67 \%$ & $56 \%$ & $62 \%$ & $100 \%$ & $33 \%$ & $52 \%$ & $67 \%$ & $56 \%$ \\
\hline
\end{tabular}

Source: own calculation. 


\section{Concluding remarks}

The research period covers years 1995 to 2015. Buy-and-hold and cumulative returns are observed both for all companies, as well as for small and large companies listed on the Warsaw Stock Exchange in Poland. Results for the Polish equity market are similar to the previously detected for other markets where also various market anomalies were detected. However, the level of reported returns is sometimes different.

Differences in average monthly returns seem to be pronounced. April, January, December and February were the bull months on the Polish stock exchange. The bear months were May, September, November and October.

Slightly higher market returns were reported in the first half of the month for both large companies and the whole market. The differences between the first and the second half of the month becomes considerable for small companies where averagely higher returns were reported for the second half of the month.

Average returns for the turn-of-the-month were much higher in comparison to the five-day periods before and after TOM. This was observed both for the whole market as well as for the large and small companies.

The January barometer anomaly was observed most often for small companies. However, such anomalous price behaviour remains disputable for the whole market and large firms.

Some of the monthly anomalies still seem to be a robust phenomenon in the Polish capital market, which is especially true for small companies. The research makes up an element of the discussion around the efficiency of emerging market and market anomalies detection. The results are of preliminary nature and as such form an introduction to the broad and multidimensional observation of seasonal anomalies for the capital market in Poland.

\section{References}

Agrawal, A., Tandon, K. (1994). Anomalies or illusions? Evidence from stock markets in eighteen countries. Journal of international Money and Finance, 13 (1), 83-106.

Ariel, R.A. (1987). A monthly effect in stock returns. Journal of Financial Economics, 18 (1), 161-174.

Booth, G.G., Kallunki, J.P., Martikainen, T. (2001). Liquidity and the turn-of-the-month effect: evidence from Finland. Journal of International Financial Markets, Institutions and Money, 11 (2), 137-146.

Brown, L.D., Luo, L. (2006). The January barometer: further evidence. Journal of Investing, 15 (1), 25-31.

Cadsby, C.B., Ratner, M. (1992). Turn-of-month and pre-holiday effects on stock returns: Some international evidence. Journal of Banking \& Finance, 16 (3), 497-509.

Czekaj, J., Woś, M., Żarnowski, J. (2001). Efektywność giełdowego rynku akcji w Polsce. Z perspektywy dziesięciolecia. Warszawa: Wydawnictwo Naukowe PWN.

Dudzińska-Baryła, R., Michalska, E. (2010). Efekt miesiąca a behawioralne aspekty podejmowania decyzji. Prace Naukowe Uniwersytetu Ekonomicznego w Katowicach. Metody i zastosowania badań operacyjnych, 10, $54-75$.

Dzhabarov, C., Ziemba, W.T. (2010). Do seasonal anomalies still work? Journal of Portfolio Management, 36 (3), 93-104. 
Dzhabarov, C., Ziemba, W.T. (2011). Seasonal anomalies. The Handbook of Equity Market Anomalies: Translating Market Inefficiencies into Effective Investment Strategies, 205-264.

Fiszeder, P., Kożuchowska, J. (2013). Testowanie występowania wybranych anomalii kalendarzowych na GPW w Warszawie. Prace Naukowe Uniwersytetu Ekonomicznego w Katowicach. Zastosowanie metod ilościowych w zarzadzaniu ryzykiem w działalności inwestycyjnej, 217-229.

French, K.R. (1980). Stock returns and the weekend effect. Journal of Financial Economics, 8 (1), 55-69.

Gibbons, M.R., Hess, P. (1981). Day of the week effects and asset returns. Journal of Business, 54 (4), 579-596.

Hensel, C.R., Ziemba, W.T. (1995). The January barometer. The Journal of Investing, 4 (2), 67-70.

Hirsch, Y. (1986). The Stock Trader's Almanac.

Khaled, M.S., Keef, S.P. (2012). A note on the turn of the month and year effects in international stock returns. European Journal of Finance, 18 (6), 597-602.

Lakonishok, J., Smidt, S. (1988). Are seasonal anomalies real? A ninety-year perspective. Review of Financial Studies, 1 (4), 403-425.

Skrodzka, W., Włodarczyk, A. (2004). Anomalie kalendarzowe na polskim rynku finansowym. Wiadomości Statystyczne, 5, 37-53.

Szyszka, A. (1999). Efektywność rynku a anomalie w rozkładzie stóp zwrotu w czasie. Nasz Rynek Kapitałowy, $108,55-61$.

Szyszka, A. (2003). Efektywność Giełdy Papierów Wartościowych w Warszawie na tle rynków dojrzałych. Poznań: Wydawnictwo Akademii Ekonomicznej w Poznaniu.

Waszkowski, A. (2013). Efektywność informacyjna rynku finansowego w Polsce. Prace Naukowe Wyższej Szkoty Bankowej w Gdańsku, 27, 59-68.

Tarczyński, W. (1997). Efektywność działania Giełdy Papierów Wartościowych w Warszawie. Ekonomista, 4, 521-538.

Thaler, R.H. (1987). Anomalies: The January effect. Journal of Economic Perspectives, 1 (1), 197-201.

Zarzecki, D., Malec, K. (2007). Anomalie na rynkach kapitałowych. Zeszyty Naukowe Uniwersytetu Szczecińskiego. Prace Instytutu Ekonomiki i Organizacji Przedsiębiorstw, 50/1, 347-363.

\section{ANOMALIE NA RYNKU WSCHODZĄCYM - EFEKTY MIESIĘCZNE DLA GIELDY PAPIERÓW WARTOŚCIOWYCH W WARSZAWIE}

Streszczenie: $\mathrm{Cel}$ - Sezonowość stóp zwrotu na rynku akcji nie po raz pierwszy jest przedmiotem badań empirycznych, zazwyczaj podejmowanych w kontekście efektywności rynku. Dotychczasowe badania dla rynku polskiego prowadzone były w dużej mierze dla wcześniejszych etapów rozwoju rynku kapitałowego.

Metodologia badania - Badania empiryczne koncentrują się na stopach zwrotu z akcji spółek notowanych na Giełdzie Papierów Wartościowych w Warszawie, uwzględniając anomalie sezonowe w okresie 1995-2015. Na podstawie skumulowanych stóp zwrotu i stóp zwrotu typu „kup i trzymaj” obserwowano zróżnicowanie miesięcznych stóp zwrotu, efekt połowy miesiąca, efekt stycznia jako barometru oraz efekt przełomu miesiąca. Wynik - Zaobserwowano znaczące równice w poziomie przeciętnych stóp zwrotu dla poszczególnych miesięcy. Efekt połowy miesiąca był szczególnie silny dla spółek mniejszych, dla których w drugiej połowie miesiąca stopy zwrotu były relatywnie wysokie. Dla całego rynku w okresie przełomu miesiąca zaobserwowano relatywnie wysokie stopy zwrotu. Efekt stycznia jako barometru był charakterystyczny tylko dla mniejszych spółek. Oryginalność/Wartość - Badania koncentrowały się na anomaliach miesięcznych dla polskiego rynku akcji w okresie ostatnich dwudziestu jeden lat, a analizę poszerzono o efekt wielkości spółek.

Słowa kluczowe: rynek wschodzący, anomalie rynkowe, efekty kalendarzowe, anomalie sezonowe, anomalie miesięczne

\section{Cytowanie}

Lizińska, J. (2017). Emerging market regularities - the case of monthly effects on the Warsaw Stock Exchange. Finanse, Rynki Finansowe, Ubezpieczenia, 2 (86), 353-362. DOI: 10.18276/frfu.2017.86-29. 